\title{
World and Indian agriculture: Revolutions \& multi speed strategies for future
}

\author{
M. B. Dastagiri ${ }^{1}$, MNV Prasad Gajula ${ }^{2}$, Ganeshagouda I. Patil ${ }^{3}$ \\ ${ }^{1}$ Principal Scientist, National Centre for Agricultural Economics and Policy Research, New Delhi, India \\ ${ }^{2}$ Scientist, Ramanujan fellow, Institute of Biotechnology, ANGR Agricultural University, Hyderabad, India \\ ${ }^{3}$ Scientist, National Centre for Agricultural Economics and Policy Research, New Delhi, India
}

\section{Email address:}

dgiri_mb@yahoo.co.in (M. B. Dastagiri)

\section{To cite this article:}

M. B. Dastagiri, MNV Prasad Gajula, Ganeshagouda I. Patil. World and Indian Agriculture: Revolutions \& Multi Speed Strategies for Future. Science Discovery. Vol. 2, No. 1, 2014, pp. 14-26. doi: 10.11648/j.sd.20140201.12

\begin{abstract}
The act of Malthusian theory of population and his prediction 'population tended to outstrip the food supply' did not happen in most parts of the globe and in India due to revolutions in agriculture. This research paper attempts to analyze and demonstrate various agricultural revolutions that occurred in India and across the globe. On this account the history of Indian agriculture has been glorious attributable mainly to green revolution and subsequent revolutions like white, blue, yellow, brown, feather and red revolutions. Similarly, the world super agriculture attributes Neolithic, Arab, Scottish, British and Green revolutions. This study emphasizes that scientists and policymakers can take significant steps towards achieving sustainable food security for the entire world's populations by adopting the strengths of the various Agricultural Revolutions while seeking to avoid its weaknesses. The production and productivity of Indian all crops were increased at increasing rate in post green revolution period witnessing operation of Law of increasing production.
\end{abstract}

Keywords: Agriculture, Revolutions, Multispeed Strategies, World, India

\section{Introduction}

Malthus' theory of population growth doubling was based on the preceding 25 years of the brand-new United States of America. Over the two hundred years following Malthus's projections, famine has overtaken numerous individual regions. Proponents of this theory, NeoMalthusians, state that these famines were examples of Malthusian catastrophes. On a global scale, however, food production has grown faster than population due to transformational advances in agricultural technology. It has often been argued that future pressures on food production, combined with threats to other aspects of the earth's habitat such as global warming, overpopulation a still more serious threat in the future. Hitherto, the act of Malthusian theory of population and his prediction 'population tended to outstrip the food supply' did not happen in Indian situation in the post Independence period. On this account the history of Indian agriculture has been glorious, attributable mainly to green revolution and subsequent revolutions like white, blue, yellow, brown, feather and red revolutions.
Global food crises are turning out to be far too frequent to be dismissed any longer as a freakish phenomenon. A spike in the prices of agricultural commodities in international prices skyrocketed to their highest in 30 years ${ }^{1}$. FAO report 2011 emphasis agricultural investment is essential for promoting agricultural growth, reducing poverty and hunger, and promoting environmental sustainability ${ }^{2}$.

Agriculture in the 21 st century has multiple challenges. It has to produce more food and fiber to feed a growing population with a smaller rural labor force, more feed stocks for a potentially huge bioenergy market, contribute to overall development in the many agriculture- dependent developing sustainable production methods and adapt to climate change ${ }^{3}$. However, when we look back into history, it is apparent that the food production and supplies are selfsufficient for decades of human life nevertheless with noticeable uneven distribution of food supplies across the globe. Therefore many revolutionary events occurred in the field of agriculture which further leads to growth \& development across the globe. However, it is also necessary to understand the drawbacks of various revolutions while learning from the strengths out of it. In 
this context this study focuses on understanding the food production process and its impact on human life in the past, current in the perspective of better future.

The green revolution, like all revolutions, brought its own problems. It bypassed millions of resource-poor farmers and had un-intended environmental and social consequences ${ }^{4}$. Moreover, the pressures of hunger and poverty, environmental degradation, and growing population are now menacing the gains generated during the 1960's and 1970's. There is apprehension that this would lead to crisis in the $21^{\text {st }}$ century. What is needed is nothing less than a series of new green revolutions. To be more precise, we need series of second green revolutions environment-friendly, mini green revolutions suitable to the diverse physical and socio-economic conditions.

Experts and the public express various opinions reflecting pessimism, optimism, anxiety and complacency, about the country's food situation and outlook in the next millennium. Since independence the food situation improved tremendously. For the past several decades, the rate of growth in India's food production exceeded the population growth rate. But by the 1980's and 1990's, the increasing scarcity of land and plateaus in yield had begun to limit the expansion of food production ${ }^{5}$. The present paper look into firstly, history of growth rates of area, production and yield since independence under different epochs of technological periods and discusses options to make future of Indian agriculture as glorious as it's past. Secondly, does metaanalysis on world agricultural revolutions collected from published secondary sources including online resources. Finally, the strategies and future options are suggested for each crop to increase further yields.

\section{Methodology of the Study}

The study has been undertaken in order to analyze the revolutionary scientific methods which brought different revolutions in different sectors in agriculture and allied sectors. It measures the performance of agriculture and allied sectors' growth during various revolutionary periods since independence era of India. For fulfilling objectives of the study, it relies exclusively on the secondary data on area, production and productivity of important agricultural crops like cereals, pulses, food crops, fibers crops and nonfood crops were collected from the FAO statistics, FAO year book, Central Statistical Organization (CSO), FAO OECD reports, and Department of Agricultural and Cooperation, Ministry of Agriculture, Govt. of India from period of $1950-51$ to $2010-11$. The other important sources are the University of Florida Digital Collections (UFDC) information. Similarly the major livestock products data on milk, eggs, wool and fisheries were sourced from the Department of Animal Husbandry Dairying \& Fisheries, Govt. of India during the same periods. The analytical tools employed for the study are compound annual growth rates and graphical analysis in order to assess the performance during different periods like pre green revolution, green revolution and post green revolution. Further, the detailed explanation of the growth rates are described in section 5 of this article. The meta-analysis done on historical world agricultural revolutions collected from published secondary sources and websites.

Compound Annual Growth rate formulae:

The compound growth rate was calculated by fitting exponential function to the area, production and productivity for the period $1950-51$ to $2010-11$.

$$
Y_{t}=a b^{t}
$$

Where,

$\mathrm{Yt}=$ Area, Production and Productivity

$\mathrm{t}=$ time variable $(1,2, \ldots, \mathrm{n})$ for each period/year

$\mathrm{a}=$ constant

$\mathrm{b}=(1+\mathrm{r})$ and

$\mathrm{r}=$ compound growth rate

\section{Meta-Analysis of World Agricultural Revolutions}

\subsection{Agricultural Revolution / Agrarian Revolution across the Globe}

Gradual transformation of the traditional agricultural system referred to as 'Agricultural Revolutions' that were taken place across the globe brought drastic changes in the lives of human. Aspects of this complex transformation that was lasted for several decades to centuries included the technical improvements, expansion of farming lands, scientific methods of breeding, soil nutrition, and experimentation with new crops, crop rotations, imports and exports.

Major agricultural revolutions across the globe in a chronological order are presented below describing noticeable transformation in the field of agriculture with respect to food productivity.

\subsubsection{Neolithic Revolution (Around 10,000 BC): The Initial Transition from Hunting and Gathering to Settled Agriculture in Prehistory}

The Neolithic Revolution or Neolithic Demographic Transition, occasionally referred to as Agricultural Revolution, was the world's first historically notable revolution in agriculture ${ }^{6}$. It was the diverse transition of various human cultures since the time of hunting and gathering of food to farming and settlement which supported a gradually increasing human population. Historical data also indicates that the domestication of various forms of plants and animals evolved in discrete locations worldwide happening since more than 12,000years ago starting from the geological era of the Holocene ${ }^{7}$. It is evident from the literature that the Neolithic Revolution considered various aspects just far more than the simple food producing techniques. During the next millennia a radical modification occurred when the mobile hunter-gatherers that dominated 
human history for several decades or even centuries transformed into stable societies by forming small sub units often referred to as villages and towns. Upon stabilized lifestyle they slowly modified their native surroundings by means of specialized food-crop cultivation followed by irrigation and various food storage mechanisms that helped to attain surplus food production. This ultimately led to development of stable high population density settlements, trading, culture, science and civilization. Lands of Eastern Sumerian (ca, 5500 BC) seem to be the major examples of social societies formed during Neolithic revolution ${ }^{8}$. American Geophysical Union, geologist Matt Konfrist argued that new geological records point to an extended period of drought that began around 2200 B.C.E., with increased rates of evaporation in both the Dead Sea and the Red Sea and lower rainfall across much of the Near East. During this period of drought, archaeology shows that nearly 75 percent of ancient Mesopotamian settlements were abandoned, while waves of marauding invaders took up residence in former Sumerian areas, effectively bringing Sumerian civilization to an end. The influence of Neolithic revolution on agriculture certainly seems to lead to key developments in food production methodologies rather than just being outcome of universal laws of social evolution? ${ }^{9}$.

\subsubsection{The Arab Agricultural Revolution}

(8th-13thcenturies): Diffusion of Crops and Farming Techniques across the Lands Lead to Economy, Population Distribution and Growth

The Arab Agricultural Revolution or Medieval Green Revolution is another breakthrough in the history of agriculture $^{10}$. According to legendary historian, Andrew Watson, a visible transformation in agriculture occurred when the diffusion of crops taken place through the Islamic world during $8^{\text {th }}-13^{\text {th }}$ centuries ${ }^{10}$. During this period, a stable economy that was established in between Arab and other Muslim traders across the globe enabled the diffusion of many crops and farming techniques among different parts of the Islamic world. Beyond the simple trade across Islamic land, the adaptation of new crops and farming techniques later spread to and from the other parts of the world during this revolution era. Various regional crops from India such as rice, cotton, mangoes were distributed throughout the Islamic lands that were never grown these crops earlier ${ }^{11}$. Similarly crops from China such as citrus fruits, crops from Africa such as Sorghum were spread to other parts of the world ${ }^{12}$. The crop distribution to nonnative lands forced the farmers to adopt new mechanization of agriculture to sustain and improve the crop production. This led to agricultural production and income, population distribution, urban growth, distribution of the labor force, linked industries ${ }^{10 .}$ However, Michael Decke, (2009) challenges the opinion of Watson's central thesis about Arab agricultural revolution citing that widespread cultivation and consumption of staples such as sorghum, rice, wheat as well as cotton were already commonplace under the Roman Empire centuries before the Islamic period $^{13}$ also cited the usage of advanced state of ancient irrigation practices like using waterwheels, several kinds of water pumps by Greek and Roman farmers long before the Muslim conquests. However, another historian E. Ashtor also negating Watson's theory about Arab revolution arguing that agricultural production was drastically declined in areas under Muslim rule because of the excruciating taxes collected on cultivated area ${ }^{14}$.

\subsubsection{The British Agricultural Revolution (17th-19th centuries): Improved Farming Techniques (Adding Plant Nutrients to Soil), Usage of Tools and Machinery for Higher Crop Yielding Lead to Industrial Revolution}

The British Agricultural Revolution describes a period of agricultural development in Britain between the 15th century and the end of the 19th century, which saw an increase in productivity and net output that broke the historical food scarcity $\operatorname{cycles}^{15}$. One of the keys to the British Agricultural Revolution was the development of ways of keeping and improving the arable land in Great Britain to counteract the loss of the soil's plant nutrients in cropping a given area ${ }^{16}$. Higher yielding land was added to higher yielding crops with more yield/acre. Farm workers using more productive tools and machinery produced more crops with fewer workers. The Agricultural Revolution picked up speed as the Industrial Revolution and the advances in chemistry produced the scientific knowledge, wealth and technology for a more systematic development of commercial fertilizers and new and more productive agricultural machinery. New crops like potatoes (introduced about 1600) and corn were introduced from the Americas improving the yield/acre of arable land ${ }^{17}$.

The British agricultural revolution, the British Industrial Revolution and Scientific Revolution developed in lockstep. Without increasing amounts of food to feed the increasing city populations the Industrial and Scientific Revolutions could not have proceeded ${ }^{18}$.

\subsubsection{The Scottish Agricultural Revolution (17th-19th Centuries): Bringing of More Land into Cultivation, Usage of Tools for Farming and Exchange of Knowledge for Improvement of Cropping Techniques}

The traditional system of agriculture in Lowland Scotland had existed unchanged for hundreds of years. In many ways it was a totally rural economy, the land being worked by the cottars on the centuries-old run system of subsistence farming ${ }^{19}$. The Agricultural Revolution in Scotland was a series of changes in agricultural practice that began in the seventeenth century and continued in the nineteenth century. Along with changes in traditional agricultural practices, many small settlements were dismantled forcing the people to find opportunities to own and farm their own land during this period. Landowners created large farms and rented them to tenant farmers with indefinite tenure and that land was mainly used to raise various crops and animals. For these families fishing, spinning of linen and military service 
became important sources of additional revenue that took dramatic change in their living conditions. Arable land spread at the expense of forests also taken place across the Scottish region. New tools such as the metal plough and seed drill meant that one man could do work that had formerly taken many men to do. Exchange of knowledge for improvement of cropping techniques was possible due to lots of migrations from and to Scotland. This revolutionary transformation brought one of the least modernized systems in the agricultural history till that time, into what was to become the most modern and productive system in Europe. During this period potatoes were grown widely for the first time throughout Scottish farm fields ${ }^{20}$.

\subsubsection{Green Revolution (1940-1970): Research, Development, and Technology Transfer Initiatives Aided Enhanced Agricultural Productivity Worldwide}

Green Revolution refers to a series of research, development, and technology transfer initiatives, occurring between the 1940s and the late 1970s that increased agriculture production worldwide, particularly in the developing world beginning most markedly in the late 1960s. The initiatives, led by Norman Borlaug, the "Father of the Green Revolution" credited with saving over a billion people from starvation, involved the development of high-yielding varieties of cereal grains, expansion of irrigation infrastructure, modernization of management techniques, distribution of hybridized seeds, synthetic fertilizers, and pesticides to farmers ${ }^{21}$.

The term "Green Revolution" was first used in 1968 by former United States Agency for International Development (USAID) director William Gaud, who noted the spread of the new technologies: According to William Gaud, "These and other developments in the field of agriculture contain the makings of a new revolution. It is not a violent Red Revolution like that of the Soviets, nor is it a White Revolution like that of the Shah of Iran. He called it the Green Revolution."

\section{Major Agricultural Revolution in India \& Past Achievements}

\subsection{Green Revolution}

Green revolution was a sort of miracle in Indian agriculture, which occurred with the introduction of high yielding varieties. Mexican dwarf varieties of wheat were tried on a selective basis in 1963-64. Paddy seeds of exotic varieties such as Taichung native-1 were introduced in 1965. The extensive cultivation of various high yielding varieties (HYV's), over a fairly large area, was taken up as a full-fledged program from Khari 1966 onwards which marked the beginning of the Green Revolution. The green revolution can be termed as most remarkable success stories after independence as it changed the life of about $70 \%$ population dependent on agriculture ${ }^{22}$. Nearly 5-time increase in production of food grains (50 to 257 million tonnes) has resulted in a buffer stock of 55.49 million tonnes and export of more than 7.46 and 4.27 million tonnes of rice and wheat respectively in 2012. The 4-fold increase in oilseed production ( 8 to 30 million) rescued the country from huge import of edible oil. The production of fruits and vegetables has increased 3 times in last 50 years and we are the second largest producers in the world. Potato revolution is almost parallel to that of wheat and perhaps of higher magnitude than of rice.

Table 1. List of major agricultural revolutions in India, major production impact and approximate time period.

\begin{tabular}{|c|c|c|}
\hline Revolution & Production & Period \\
\hline Green Revolution & $\begin{array}{l}\text { Food grain (Cereals, Wheat } \\
\text { \&Leguminous plant) production }\end{array}$ & $1966-67$ \\
\hline White Revolution & $\begin{array}{l}\text { Milk/Dairy production (In India - } \\
\text { Operation Flood) }\end{array}$ & $1970-96$ \\
\hline Blue Revolution & Fish Production & $1973-2002$ \\
\hline Brown Revolution & $\begin{array}{l}\text { Leather/non- } \\
\text { conventional(India)/Cocoa } \\
\text { production }\end{array}$ & --- \\
\hline Pink Revolution & $\begin{array}{l}\text { Onion production/Pharmaceutical } \\
\text { (India)/Prawn production }\end{array}$ & 1970’s \\
\hline Round Revolution & Potato Revolution & $1965-2005$ \\
\hline Yellow Revolution & Oil Seeds production & $1986-90$ \\
\hline Red Revolution & Meat \& Tomato Production & 1980’s \\
\hline $\begin{array}{l}\text { Golden Fiber } \\
\text { Revolution }\end{array}$ & Jute Production & 1990’s \\
\hline Golden Revolution & $\begin{array}{l}\text { Overall Horticulture } \\
\text { development/Honey Production }\end{array}$ & $1991-2003$ \\
\hline Grey Revolution & Fertilizer Revolution & $\begin{array}{l}1960 \text { 's- } \\
1970 \text { 's }\end{array}$ \\
\hline $\begin{array}{l}\text { Silver Fiber } \\
\text { Revolution }\end{array}$ & Cotton Revolution & 2000’s \\
\hline Silver Revolution & Egg/Poultry Production & 2000’s \\
\hline $\begin{array}{l}\text { Evergreen } \\
\text { Revolution }\end{array}$ & Overall development of Agriculture & --- \\
\hline
\end{tabular}

Impacts of Green Revolution:

A revolution of this magnitude was bound to create some problems of its own. Critics charged that the Green Revolution resulted in environmental degradation and increased income inequality, inequitable asset distribution, and worsened absolute poverty. Some of these criticisms are valid and have been or still need to be addressed ${ }^{23}$.

Positive Impacts:

Increased income:

The Green Revolution led to sizable increases in returns to land, and hence raised farmers' incomes. Moreover, with greater income to spend, new needs for farm inputs, and milling and marketing services, farm families led a general increase in demand for goods and services. This stimulated the rural nonfarm economy, which in turn grew and generated significant new income and employment of its own. Real per capita incomes almost doubled in Asia between 1970 and 1995, and poverty declined from nearly three out of every five Asians in 1975 to less than one in three by 1995.The absolute number of poor people fell from 1.15 billion in 1975 to 825 million in 1995 despite a 60 percent increase in population. 
In India, the percentage of the rural population living below the poverty line fluctuated between 50 and 65 percent before the mid-1960s but then declined steadily to about one-third of the rural population by 1993. Research studies show that much of this steady decline in poverty is attributable to agricultural growth and associated declines in food prices.

Better Nutrition:

The Green Revolution also contributed to better nutrition by raising incomes and reducing prices, which permitted people to consume more calories and a more diversified diet. Big increases occurred in per capita consumption of vegetable oils, fruits, vegetables, and livestock products in Asia.

Negative Impacts:

Critics charged that the Green Revolution resulted in environmental degradation and increased income inequality, inequitable asset distribution, and worsened absolute poverty. Some of these criticisms are valid and have been or still need to be addressed.

The Green Revolution in Asia stimulated a large body of empirical literature on how agricultural technological change affects poor farmers. Critics of the Green Revolution argued that owners of large farms were the main adopters of the new technologies because of their better access to irrigation water, fertilizers, seeds, and credit. Small farmers were either unaffected or harmed because the Green Revolution resulted in lower product prices, higher input prices, and efforts by landlords to increase rents or force tenants off the land. Critics also argued that the Green Revolution encouraged unnecessary mechanization, thereby pushing down rural wages and employment. Although a number of village and household studies conducted soon after the release of Green Revolution technologies lent some support to early critics, more recent evidence shows mixed outcomes. Small farmers did lag behind large farmers in adopting Green Revolution technologies, yet many of them eventually did so. Many of these small-farm adopters benefited from increased production, greater employment opportunities, and higher wages in the agricultural and nonfarm sectors.

Moreover, most small holders were able to keep their land and experienced significant increases in total production. In some cases, small farmers and landless laborers actually ended up gaining proportionally more income than larger farmers, resulting in a net improvement in the distribution of village income. Development practitioners now have a better understanding of the conditions under which the Green Revolution and similar yield-enhancing technologies are likely to have equitable benefits among farmers.

These conditions include:

(1) a scale-neutral technology package that can be profitably adopted on farms of all sizes;

(2) an equitable distribution of land with secure ownership or tenancy rights;

(3) efficient input, credit, and product markets so that farms of all sizes have access to modern farm inputs and information and are able to receive similar prices for their products; and

(4) Policies that do not discriminate against small farms and landless laborers (for instance, no subsidies on mechanization and no scale biases in agricultural research and extension).

These conditions are not easy to meet. Typically, governments must make a concerted effort to ensure that small farmers have fair access to land, knowledge, and modern inputs.

Another shortcoming of the Green Revolution was that it spread only in irrigated and high-potential rainfed areas, and many villages or regions without access to sufficient water were left out. Although evidence suggests that even in these cases villagers obtained important indirect benefits through increased employment and migration opportunities and cheaper food, the benefits were rarely sufficient to prevent further widening of income gaps. In India, for example, poverty in many low-potential rain fed areas has improved little even while irrigated and high-potential rain fed areas have progressed.

Regional inequalities have worsened in China as well. The Green Revolution has also been widely criticized for causing environmental damage. Excessive and inappropriate use of fertilizers and pesticides has polluted waterways, poisoned agricultural workers, and killed beneficial insects and other wildlife. Irrigation practices have led to salt build-up and eventual abandonment of some of the best farming lands. Groundwater levels are retreating in areas where more water is being pumped for irrigation than can be replenished by the rains. And heavy dependence on a few major cereal varieties has led to loss of biodiversity on farms. Some of these outcomes were inevitable as millions of largely illiterate farmers began to use modern inputs for the first time, but inadequate extension and training, an absence of effective regulation of water quality, and input pricing and subsidy policies that made modern inputs too cheap and encouraged excessive use also created negative environmental impacts. These problems are slowly being rectified without yield loss, and sometimes with yield increases, thanks to policy reforms and improved technologies and management practices, such as pest-resistant varieties, biological pest control, precision farming, and crop diversification.

Often ignored, however, is the positive impact of higher yields in saving huge areas of forest and other environmentally fragile lands that would otherwise have been needed for farming. In Asia cereal production doubled between 1970 and 1975, yet the total land area cultivated with cereals increased by only 4 percent 23 .

First GR: Diffusion and Impact of Crop Genetic Improvements

Positive impacts on poverty reduction and lower food prices were driven in large part by crop germplasm improvements in renowned CGIAR centers that were then transferred to national agricultural programs for adaptation and dissemination. The productivity gains from crop germplasm improvement alone are estimated to have 
averaged $1.0 \%$ per annum for wheat (across all regions), $0.8 \%$ for rice, $0.7 \%$ for maize, and $0.5 \%$ and $0.6 \%$ for sorghum and millets, respectively ${ }^{24,25}$.

Impact on Productivity and Food Prices:

Widespread adoption of GR technologies led to a significant shift in the food supply function, contributing to a fall in real food prices. Between 1960 and 1990, food supply in developing countries increased 12-13\%. Estimates suggest that, without the CGIAR and national program crop germplasm improvement efforts, food production in developing countries would have been almost 20\% lower 24, 25.

Nutrition: Calorie Availability Increases but Micronutrient intake is Still Lagging.

Nutritional gains of the GR have been uneven; although overall calorie consumption increased, dietary diversity decreased for many poor people, and micronutrient malnutrition persisted. In some cases, traditional crops that were important sources of critical micronutrients (such as iron, vitamin A, and zinc) were displaced in favor of the higher-value staple crops 26

Impact on environment:

Unintended consequences in water use, soil degradation, and chemical runoff have had serious environmental impacts beyond the areas cultivated 59, 60. The slowdown in yield growth that has been observed since the mid-1980s can be attributed, in part, to the above degradation of the agricultural re-source base. These environmental costs are widely recognized as a potential threat to the long-term sustainability and replication of the GR's success 59, 60 .

\subsection{Ever Green Revolution}

Renowned as Father of Ever Green revolution in India, Swaminathan emphasized the need to improve productivity in perpetuity without associated ecological and/or social harm ${ }^{29}$.

Exploitive agriculture offers great dangers if carried out with only an immediate profit or production motive. The emerging exploitive farming community in India should become aware of this. Intensive cultivation of land without conservation of soil fertility and soil structure would lead, ultimately, to the springing up of deserts. Irrigation without arrangements for drainage would result in soils getting alkaline or saline. Indiscriminate use of pesticides, fungicides and herbicides could cause adverse changes in biological balance as well as lead to an increase in the incidence of cancer and other diseases, through the toxic residues present in the grains or other edible parts. Unscientific tapping of underground water will lead to the rapid exhaustion of this wonderful capital resource left to us through ages of natural farming. The rapid replacement of numerous locally adapted varieties with one or two high-yielding strains in large contiguous areas would result in the spread of serious diseases capable of wiping out entire crops, as happened prior to the Irish potato famine of 1854 and the Bengal rice famine in 1942. Therefore the initiation of exploitive agriculture without a proper understanding of the various con-sequences of every one of the changes introduced into traditional agriculture, and without first building up a proper scientific and training base to sustain it, may only lead us, in the long run, into an era of agricultural disaster rather than one of agricultural prosperity ${ }^{29}$.

\subsection{White Revolution}

The story of white revolution in India is basically the success story of dairy cooperative movement in the country and the Operation Flood Program launched by government of India with international cooperation. The white revolution is intended to be at one and the same time parallel, complementary, supplementary and corrective to the green revolution. 'White' has increased livestock production while the 'green' enhanced crops output. But both have of helped in terms of nutritive gains the green revolution provided calories, while the white revolution provided protein.

In addition to these productive gains, the skewed distribution of returns from the green revolution was set right to some extent by its white successor. Small and marginal farmers whose holdings were not suited to green revolution technology could be inducted into the alternative productive process of dairying, which does not require a large land base. Furthermore, agricultural labourers who are displaced from employment by mechanization could be provided compensatory employment and income from dairying.

The record milk production of about 112.5 million tonnes in 2009-10 has made India the highest milk producer in the world. We have emerged as the major exporter of animal vaccines and various animal-based raw materials of industrial importance. Our poultry industry is growing at the rate of $8-10 \%$ for eggs and $15-20 \%$ for broiler owing to improved breed and modern management ${ }^{29,30}$.

\subsection{Yellow Revolution}

The dramatic transformation of the Indian oilseeds production scenario from a "net importer" status in the Eighties to a near self-sufficient" status during the early Nineties has been popularly termed as the "Yellow Revolution". From a mere 11 million tonnes during 1986-87, the country succeeded an all - time record oilseeds production of 32 million tonnes during 2010-11, just in the span of a decade. The main contributors to such a significant transformation are; the oil seeds production technology, expansion in area under oilseed, price and market intervention support policy and the institutional support, particularly the formation of the Technology Mission on Oilseeds in 1986, among others. Though, pulses and oilseeds production did not witness significant growth till 1980-81, the latter experienced spectacular increase in area, yield and production, whereas the pulses remained stagnant.

\subsection{Blue Revolution}

India is the second largest fish producer in the world with a share of 5.43 per cent of the total fish produced 
world wide, preceded only by china as per FAO statistics 2009. Indian freshwater aquaculture has grown rapidly during the last two decades, now contributes a third to the total fish production of 7.91 million tonnes. Further, the share of the inland sector in total fish production has risen from 29 percent in 1950-51 to over 61 percent in 2010-11. Aquaculture production increased from about 5.1 lakh tonnes in 1984 to 4.3 million tonnes during 2011-12. Fresh water aquaculture sector has potentials for both horizontal expansion of area and for vertical increase in productivity from the national average of 2 tonnes/ha/year to 3-5 tonnes ha/year in the years to come. Scope for its diversification, compatibility with other farming systems, availability of a host of plenty culture systems and flexibility with regard to input levels and scales of investment show the prospects and potentials of freshwater aquaculture. Fisheries played an important role in boosting the economy of the country. It helped in augmenting food supply, generating employment, raising nutritional level and earning foreign exchange. Fish production has increased at an average annual growth rate of 2.91 per cent during 2010-11 ${ }^{32}$. Considering the developments already made and the possibilities, it may be said that fresh water aquaculture in the country is on the threshold of a blue revolution ${ }^{30}$.

\section{Results and Discussions}

\subsection{Growth Rates of area, Production and Productivity of Major Crops}

India's crop production trend during 1950-51 to 2010-11 can be divided into three distinct phases. These are

I. Pre green revolution period - 1950-51 to 1964-65

II. Green revolution period - $1967-68$ to $1980-81$

III. Post green revolution period - 1981-82 to 2011-12

In the following sections achievements of crop sectors and major crops are discussed during these phases.

\subsection{Crop sectors Performance}

The growth rates experienced by broad crop groups in different phages are shown in Table 1.

\subsubsection{Cereals Crops}

During the whole period from $1967-68$ to $2011-12$, the annual compound growth rate of cereals were -0.01 percent, 2.39 per cent and 2.15 per cent respectively. The same variables during the period of green revolution were recorded as 0.38 per cent, 2.46 per cent and 1.47 per cent and in post green revolution were -0.08 per cent, 2.09 per cent and 2.00 per cent respectively. The decline in the growth rate in area of cereals during the overall period and post green revolution periods were found to be negative rate due to shift in cropping pattern to the high valuable crops. However, in the period of green revolution the area under cereals crops were found to be high due to the adoption high yielding varieties and huge subsidies from the government etc. motivated the diversion of crops into cereal crops and further, yield and production growth rate in all the periods were increasing due to technological transformation i.e. application chemical fertilizers, HYV's etc.

\subsubsection{Pulses Crops}

The growth rate in area, production, yield of pulses increased at the rate of $0.06 \%, 0.80 \%$, and $0.74 \%$ respectively during $1967-68$ to 2011-12. The same variables growth rates were increased at the rates of $0.42 \%$, $-0.53 \%,-0.95 \%$ in green revolution period and $0.02 \%$ $0.82 \%, 0.80 \%$ in post green revolution period. Though the area under pulses elevated at the rate of $0.42 \%$ in green revolution period, the production and yield growth rates were negative depicts no technological breakthroughs happening in this period. Contrastingly, though the area was increased at marginal rate $(0.02 \%)$ in post green revolution period, the production and yield growth rates were increased at the rate of $0.82 \%$ and $0.80 \%$ respectively.

\subsubsection{Food Grains Crops}

The area, production and yield growth rates under food grains were at the rate of $-0.04 \%, 2.22 \%$, and $2.26 \%$ during $1967-68$ to 2011-12. The same variables growth rates were raised at the rate of $0.39 \%, 2.27 \%, 1.87 \%$ and $-0.14 \%$, $1.89 \%, 2.03 \%$ in green and post green revolution periods respectively. The higher growth rates of production and yield during green revolution period was due to higher per hectare yield and more area under cultivation. The declined area at the rate of $-0.14 \%$ under food grains during post green revolution period was due to shift in area from food grains to non-food grains.

\subsubsection{Oilseeds Crops}

Oil seeds area, production and yield growth rates were increased at the rate of $1.46 \%, 3.39 \%$, and $1.90 \%$ respectively during 1967-68 to 2011-12. The growth rates of the same variables were elevated at the rate of $1.12 \%, 1.16 \%$, $0.53 \%$ and $1.22 \%, 3.20 \%, 1.96 \%$ in green revolution and post green revolution periods respectively. All the variables growth rates of green revolution period were too lower than post green revolution period implies up to 1980's there was no technological break through in oilseeds production. But magnificent higher growth rates of area, production and yield were attained in post green revolution period witnessing yellow revolution in oil seed production.

\subsubsection{Fibers Crops}

The area, production, yields growth rates under fibers were raised at the rate of $0.52 \%, 2.69 \%$, and $2.11 \%$ during 1967-68 to 2011-12. The corresponding variables trend rates were increased at the rate of $0.26,2.53 \%, 1.20 \%$, and $1.00 \%, 3.25 \%, 2.16 \%$ in green revolution and post green revolution periods respectively. All the variables growth rates in post green revolution period were more than green revolution period due to more area under cultivation and more productivity. The more area was allocated under fibers during post green revolution period because of high demand for exports and more foreign exchange earning. 


\subsubsection{Non - Food Grains Crops}

The area, production, yield annual compound growth rates under non-food grains for the period 1967-68 to 2011-12 were increased at the rate of $1.17 \%, 3.00 \%, 2.01 \%$ respectively. The same variables growth rates were increased at the rate of $0.81 \%, 2.18 \%, 0.88 \%$ in green revolution period and $1.15 \%, 3.21 \%, 2.07 \%$ in post green revolution period. All the variables growth rates in post green revolution period were more than green revolution period due to increased more area under cultivation and more per hectare yields. This implies that non-food grains were gained much importance during post green revolution period. The doubled in area growth rate in post green revolution period was due to shift in area from food grains to non-food grains.

\subsubsection{All Crops}

During 1967-68 to 2011-12, the area, production, yield growth rates under all crops were increased at the rate of $0.20 \%, 2.37 \%$, and $2.17 \%$. The corresponding trend parameters growth rates were elevated at the rate of $0.46 \%$, $2.25 \%, 1.48 \%$ and $0.12 \%, 2.14 \%, 2.05 \%$ in green and post green revolution periods respectively. The production and productivity were increased at increasing rate in post green revolution period witnessing operation of Law of increasing production. This was due to more technological advancement in this period.

Table 2. All - India compound growth rates of area, production and yield of crop sectors (\% Per annum).

\begin{tabular}{|c|c|c|c|c|c|c|c|c|c|}
\hline \multirow{2}{*}{ Crops } & \multicolumn{3}{|c|}{ 1967-68-67 to 2011-12 } & \multicolumn{3}{|c|}{$1967-68$ to $1980-81$} & \multicolumn{3}{|c|}{ 1981-82 to 2011-12 } \\
\hline & Area & Production & Yield & Area & Production & Yield & Area & Production & Yield \\
\hline Cereals & -0.01 & 2.39 & 2.15 & 0.38 & 2.46 & 1.47 & -0.08 & 2.09 & 2.00 \\
\hline Pulses & 0.06 & 0.80 & 0.74 & 0.42 & -0.53 & -0.95 & 0.02 & 0.82 & 0.80 \\
\hline Food grains & -0.04 & 2.22 & 2.26 & 0.39 & 2.27 & 1.87 & -0.14 & 1.89 & 2.03 \\
\hline Oilseeds & 1.46 & 3.39 & 1.90 & 1.12 & 1.66 & 0.53 & 1.22 & 3.20 & 1.96 \\
\hline Fibers & 0.52 & 2.69 & 2.11 & 0.26 & 2.53 & 1.20 & 1.00 & 3.25 & 2.16 \\
\hline Non-food grains & 1.17 & 3.00 & 2.01 & 0.81 & 2.18 & 0.88 & 1.15 & 3.21 & 2.07 \\
\hline All crops & 0.20 & 2.37 & 2.17 & 0.46 & 2.25 & 1.48 & 0.12 & 2.14 & 2.05 \\
\hline
\end{tabular}

Source: Agricultural Statistics at Glance, 2012

\subsection{Fisheries Sector}

The growth of fishery sector has been faster in the food sector. The production of fish has increased at a cumulative growth rate of $4.2 \%$ per annum since $1950-51$. The share of fisheries in GDP from agriculture has almost doubled from $1.96 \%$ in $1980-81$ to $4.39 \%$ in $2010-11^{33}$. This sector has become one of the fast-growing areas of economic activity with in the agriculture sector.

Table 3. Decade-wise trends of fish production (in million tones)

\begin{tabular}{cccc}
\hline Year & Marine & Inland & Total \\
\hline $1960-61$ & 0.88 & 0.28 & 1.16 \\
$1970-71$ & 1.08 & 0.67 & 1.75 \\
$1880-81$ & 1.55 & 0.88 & 2.44 \\
$1990-91$ & 2.30 & 1.53 & 3.83 \\
$2000-01$ & 2.81 & 2.84 & 5.65 \\
$2010-11(\mathrm{P})$ & 3.22 & 5.19 & 8.42 \\
\hline
\end{tabular}

Source: Department of Animal Husbandry Dairying \& Fisheries.

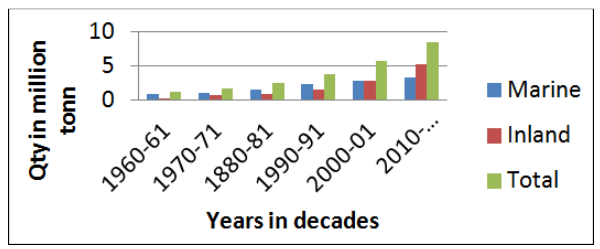

Figure 1. Fish production

The decade-wise trend of total fish production shown in table 2 reveals that over the decades the fish production was drastically increased from 1.16 million ton to 8.42 million ton during the period from first decade (1960-61) to sixth decade (2010-11). Up to 1990-91, the marine fish production was having more share than inland fish production in the total fish production. Subsequently, from 2000-01 onwards, the inland fish production was overtaken the marine fish production in the total fish production (as shown in Figure 1). However, the marine fish production had also shown increased trend in production from 0.88 million ton to 3.22 million ton over the same decades. It is obvious from the table that the fish production growth rate was not steady. So there is need to improve cultural, research and management practices of fish production.

\subsection{Livestock Sector}

In India livestock plays a vital role in rural economy as integrator of soil, crop, and animal production system. Livestock is linked with about 70 million households, majority being landless or marginal farmers. Livestock sector is characterized by large number of animals (529.70 million animals, 648.88 million birds), low productivity and low input system, but the annual growth of $6.23 \%$ per cent is almost double to that of agriculture. Cattle (199 million), Buffalo (105 million), Sheep (71 million), goat (140 million), Camel (0.52 million), and pig (11 million) are grown in a small holding integrated production system with gains more equally distributed and providing sustainability to agricultural sector. The contribution of Animal husbandry was $15.5 \%$ to the total GDP in $1950-51$ and the currently, the contribution of livestock's according to estimates of the Central Statistics Office (CSO), reported as, the value of output from livestock and fisheries sector 
together at current prices was about 4,61,434 crore during 2010-11 (3,88,370 for livestock sector and 73,064 crore for fisheries) which is about $28.4 \%$ of the value of output of $16,23,968$ crore from total agricultural and allied sector. Since, Independence the country succeeded the highest growth in this sector resulted three revolutions namely; white (milk), feather (poultry) and red (meat) revolutions ${ }^{34}$.

The decade wise compound annual growth rate of major livestock products in India have been presented in the table 3, indicates that impressive growth performance in the milk and egg production over the decades; i.e. in case of Milk, 1.64 per cent to 4.22 per cent during the decade $1960-73$ to 2001-10 and similarly, the egg production were recorded positive growth rate in all the decades from 4.63 per cent to 5.67 per cent respectively for the same periods. However, high pickup in growth rate were observed from 1970's onwards due to the enormous support from the government through the introduction of operation flood programs and development of dairy industries and increasing demand from continuous increasing population and health conscious awareness etc. While in case of wool production reported better positive growth rate from 0.32 per cent to 1.62 per cent during the decades from 1950-61 to 2000-0, after it turned as negative growth rate in production as -1.18 per cent during the period of 2000-10. This could be due to lack of technology available and also low market demand.

Table 4. Annual Growth rate of Major livestock products in India

\begin{tabular}{cccc}
\hline Years & Milk & Eggs & Wool \\
\hline $1950-51$ to $1960-61$ & 1.64 & 4.63 & 0.38 \\
$1960-61$ to $1973-74$ & 1.15 & 7.91 & 0.34 \\
$1973-74$ to $1980-81$ & 4.51 & 3.79 & 0.77 \\
$1980-81$ to $1990-91$ & 5.48 & 7.69 & 2.32 \\
$1990-91$ to $2000-01$ & 4.11 & 5.67 & 1.62 \\
2000-01 to $2010-11$ & 4.22 & 5.58 & -1.18 \\
\hline
\end{tabular}

Source: Department of Animal Husbandry Dairying \& Fisheries.

\subsection{Principal Crops Performance}

The important principal crops of each crop sectors growth rates performance are studied. These are the major contributing crops in terms of area, production and productivity to respective crops sectors. The all India compound growth rates of area, production and productivity of these crops under different periods are shown in Table 4.The future promising yield of crops sectors mainly depend on these crops. The strategies and future options are suggested for each crop to increase further yields.

\subsubsection{Paddy Crops}

The area, production and productivity under paddy rose at a rate of $0.61 \%, 2.52 \%$ and $1.90 \%$ per annum respectively during $1950-51$ to $2011-12$. The growth in area under paddy was $1.45 \%, 0.75 \%$, and $0.29 \%$ during three periods indicating increasing but at decreasing rate. Among the different periods the production growth rates were $4.35 \%, 2.18 \%$ and $2.01 \%$ respectively. During all three periods production growth rate was also increasing at decreasing rate due to the decreasing growth rate in area allocation of paddy production. However, productivity growth rates among different periods were $2.86 \%, 1.42 \%$ and $1.71 \%$ respectively and the positive growth rate in paddy yield is may be attributed usage of more fertilizer and irrigation and HYV's.

\subsubsection{Wheat Crops}

The annual compound growth rate of wheat was $1.77 \%$ in area, $4.62 \%$ in production and $2.80 \%$ of productivity during $1950-51$ to $2012-13$. But, the area allocation under different periods was $2.70 \%, 2.95 \%, 0.80 \%$. The production growth rates under different periods were $4.27 \%, 5.48 \%, 2.52 \%$. The remarkable growth rate of $5.48 \%$ during green revolution period witnessing green revolution occurred in wheat crop. The per hectare yield compound growth rates among different periods were $1.53 \%, 2.45 \%$, $1.71 \%$ shows that in all these periods the wheat productivity has been increasing.

\subsubsection{Maize Crops}

During 1950-51 to 2011-12, the annual compound growth rates of area, production and productivity were raised at the rate of $1.20 \%, 3.15 \%$, and $1.93 \%$ respectively. Over the different periods the area under maize was increased at the rate of $2.68 \%, 0.21 \%$, and $1.41 \%$. The less increase in area at the rate of $0.21 \%, 1.41 \%$ during green revolution and post green revolution period indicates that the area augmentation under maize cultivation is neglecting. The production growth rates were raised at the rate of $6.40 \%, 0.40 \%$, and $3.85 \%$. Where as productivity increased at the rate of $3.62 \%$ and $2.41 \%$ during pre and post green revolution periods.

\subsubsection{Soybean Crops}

Soybean is one of the important pulse crops is contributing much to pulse sector. The area, production, and productivity under soybean were increased at the rate of $38.95 \%, 49.76 \%$ and $6.11 \%$ during green revolution period respectively. These growth rates indicate that the importance of this crop gained momentum in this period. The quantum jump in area allocation is due to the urgency to bridge the need of pulse demand. The same variables growth rates were raised at the rate of $9.61 \%, 11.59 \%$ and $1.79 \%$ during post green revolution period respectively. The $9.41 \%$ growth in area allocation during post green revolution period implies continuously this crop gaining importance because of its nutrition and industrial importance.

\subsubsection{Groundnut Crops}

Groundnut area, production and productivity were elevated at annual compound growth rates of $0.20 \%$, $1.11 \%$, and $0.91 \%$ during $1950-51$ to $2011-12$. Among different periods the production growth rates were $4.36 \%$, $0.64 \%, 0.09 \%$. The area under allocation of groundnut cultivation showing dwindling picture as their growth rates indicates $3.84 \%,-0.30 \%$, and $-1.02 \%$ during different periods. Therefore, it indicates that, during green 
revolution (and post green revolution periods the area under groundnut cultivation was totally neglected. However, for the same periods per hectare yields are increasing at increasing rate $(0.31 \%, 0.96 \%$ and $1.96 \%)$.

\subsubsection{Cotton Crops}

During $1950-51$ to $2011-12$, the area, production and productivity under cotton increased at the rate of $0.43 \%$, $2.94 \%$, and $2.51 \%$ per annum. During different periods the area increased at the rate of $1.85 \%, 0.08 \%, 1.19 \%$ per annum indicates diminishing area allocation. The production of cotton during different periods is quiet impressive and growth rates were observed at the rate of $4.28 \%, 2.62 \%$, and $4.55 \%$ per annum. The productivity of cotton under different periods was $2.38 \%, 2.54 \%$ and $3.32 \%$ indicates productivity is increasing at increasing rate.

\subsubsection{Jute Crops}

The area, production and productivity were increased under jute cultivation at annual compound growth rates of $0.03 \%, 1.52 \%$, and $1.49 \%$ respectively during $1950-51$ to 2011-12. During different periods the area rose at the rate of $4.84 \%, 1.53 \%,-0.62 \%$ indicates drastic declining trend in land allocation under jute. Correspondingly, the production growth rates also showing declining trends $(5.45 \%, 2.59 \%$, and $1.33 \%)$ during different periods. Contrastingly, the productivity growth rates showing increasing trend for the same periods $(0.59 \%, 0.04 \%$ and $1.96 \%)$.

\subsubsection{Tobacco Crops}

The trends in area, production and productivity under tobacco observed at the rate of $0.01 \%, 1.49 \%$, and $1.47 \%$ per annum during 1950-51 to 2011-12. Over the periods, the area increased $1.75 \%$ during pre green revolution period and negative growth of $-0.08 \%$ and $-0.35 \%$ during green revolution and post green revolution period. This may be on account of Government policy restriction on allocation of area under tobacco. The production growth rates during different periods were $3.07 \%, 2.19 \%$ and $0.61 \%$ indicates declining trend. The productivity growth rates during different periods were $1.32 \%, 2.30 \%$, and $0.92 \%$.

\subsubsection{Sugarcane Crops}

The area, production and productivity under sugarcane increased at annual compound growth rate of $1.69 \%$, $3.04 \%$, and $1.33 \%$ respectively during $1950-51$ to $2011-12$. Under different periods the area growth rates were $3.19 \%$, $1.65 \%$ and $1.61 \%$ respectively. The production is increased under different periods at the rate of $6.36 \%, 2.64 \%, 2.19 \%$ per annum indicates impressive accomplishment. The productivity of sugarcane during three periods increased shown dwindling picture.

Table 5. All India compound growth rates of Area, Production \& yield of principal Crops (\% Per annum)

\begin{tabular}{|c|c|c|c|c|c|c|c|c|c|c|}
\hline \multicolumn{2}{|c|}{ Particulars } & Paddy & Wheat & Maize & Soya bean & Groundnut & Cotton & Jute & Tobacco & Sugarcane \\
\hline \multirow{3}{*}{$\begin{array}{c}1950-51 \text { to } \\
2011-12\end{array}$} & Area & 0.61 & 1.77 & 1.20 & - & 0.20 & 0.43 & 0.03 & 0.01 & 1.69 \\
\hline & Production & 2.52 & 4.62 & 3.15 & - & 1.11 & 2.94 & 1.52 & 1.49 & 3.04 \\
\hline & Yield & 1.90 & 2.80 & 1.93 & - & 0.91 & 2.51 & 1.49 & 1.47 & 1.33 \\
\hline \multirow{3}{*}{$\begin{array}{c}\text { Pre green } \\
\text { revolution } \\
\text { period: } 1950- \\
51 \text { to } 1964-65\end{array}$} & Area & 1.45 & 2.70 & 2.68 & - & 3.84 & 1.85 & 4.84 & 1.75 & 3.19 \\
\hline & Production & 4.35 & 4.27 & 6.40 & - & 4.36 & 4.28 & 5.45 & 3.07 & 6.36 \\
\hline & Yield & 2.86 & 1.53 & 3.62 & - & 0.50 & 2.38 & 0.59 & 1.32 & 3.07 \\
\hline \multirow{3}{*}{$\begin{array}{c}\text { Green } \\
\text { revolution } \\
\text { period } 1967- \\
68 \text { to } 1980-81\end{array}$} & Area & 0.75 & 2.95 & 0.21 & 38.95 & -0.30 & 0.08 & 1.53 & -0.08 & 1.65 \\
\hline & Production & 2.18 & 5.48 & 0.40 & 49.76 & 0.64 & 2.62 & 2.59 & 2.19 & 2.64 \\
\hline & Yield & 1.42 & 2.45 & 0.19 & 6.11 & 0.95 & 2.54 & 1.04 & 2.30 & 0.98 \\
\hline \multirow{3}{*}{$\begin{array}{l}\text { Post green } \\
\text { revolution } \\
\text { period: } 1980- \\
81 \text { to } 2011-12\end{array}$} & Area & 0.29 & 0.80 & 1.41 & 9.61 & -1.02 & 1.19 & -0.62 & -0.35 & 1.61 \\
\hline & Production & 2.01 & 2.52 & 3.85 & 11.59 & 0.09 & 4.55 & 1.33 & 0.61 & 2.19 \\
\hline & Yield & 1.71 & 1.71 & 2.41 & 1.79 & 1.12 & 3.32 & 1.96 & 0.92 & 0.57 \\
\hline
\end{tabular}

Source: Agricultural statistics at a glance 2012.

\subsection{Options for Future}

Based on past performance of various subsectors and crops some options for future can be discussed. The future additional or promising yields would possible by allocating more area to the crops, which have comparative yield advantage, and improving their productivity through advanced technologies.

The area under cereals during post green revolution period was declined and their productivity almost stagnated. The future promising yields in cereals would be possible through breaking the stagnated yield productivity and reallocating more area to crops, which have comparative yield advantage among cereal crops. Research must concentrate on 'orphan crops' like coarse cereals, maize, power and bare to explore the untapped potential yields ${ }^{35}$.

Among all crop sectors, pulses had been yielding the poorest yields. The negative growth rates of production and yield during green and post green revolution period were because of lack of technological breakthroughs happened in pulse production. The enormous untapped yields in future would be explored through tailoring of productive early maturing plant types of all pulses for inter cropping with wide space planted crops for different agro-climatic regions. Insulation of all pulses with a high level of resistance to major limiting pests (Halitosis and Spodoptera) 
by resorting to innovative genetic engineering is another option.

The area under food grains cultivation has been declining since post green revolution period and it may lead to shortage of food grains in the country. The higher yields of food grains in future would be possible through more area reallocation based on comparative yield advantage among themselves and improved productivity through fertilizer, irrigation responsive varieties.

$\mathrm{Up}$ to green revolution period, the growth rates of oilseeds were not impressive. But amazing achievements were made during the post green revolution period. Further yield increase in oilseeds would be possible through development and extensive cultivation of commercial viable hybrids in Brassica nepus and Brassica juncea. Possibilities of development of hybrid technology in Sesamum and sunflower need to be explored. Further, long-term efforts must continue to break yield barriers in groundnut.

Though higher productivity could be accomplishing under fibers, its area allocation has been declining continuously. In order to take comparative advantage of yields and commercial export value, the country need to allocate more area under fibers. Non -food grains sector gained much importance since post green revolution period. This sector has promising future because of more yielding ability and commercial advantage. Bhalla and Singh in 1997 reported the results of an analysis of state level data on area and output of 43 crops for the 30 years from 196265 to 1992-93. It reveals that there was a marked acceleration in the growth rate of agricultural out put in India during 1980-83 to $1992-95$ as compared with the earlier periods. Furthermore, agriculture growth had become regionally much diversified. The period $1980-83$ to 1992-95 was also characterized by important cropping pattern changes away from coarse cereals towards rice and wheat cultivation on the one hand and towards oilseeds on the other. Since 1950-51, area, production and productivity growth rates in all crops were positive and it would possible to continue the same rate. But productivity of these crops far less than the theoretical yields. So still there is room for improvement.

Fisheries sector has become one of the fast growing areas of economic activity with in the agriculture sector. The total fish production growth rate was not steady. Composite fish culture revolutionized inland fisheries. The marine fish production is more than inland fish production. Fresh water aquaculture sector has potentials for both horizontal expansion of area and vertical increase in productivity. Scope for its diversification, compatibility with other farming systems, availability of a host of plenty culture systems and flexibility with regard to input levels and scales of investment fresh water aquaculture has tremendous prospects and potentials in future. New technology with improved cultural, research and management practices would make fisheries sector more prosperous.

Livestock sector plays vital role in agriculture as integrator of soil, crop, and animal production system. The country succeeded the highest growth rates in egg and milk meat. The compound growth rates of major livestock sector were impressive implying their fastness at growth. However, wool growth was declined due to lack of technology and demand for the product. Production of suitable cross breeds of cattle, poultry birds and others and their wide adoption, technological advancement in improving productivity would lead this sector progress at faster rate.

The area allocation under paddy crop had declined and productivity almost stagnated. It needs cautious allocation of more area under paddy crop. The additional yields would possible in this crop through exploitation of the unlimited genetic variability for all traits of economic importance. The $30-40 \%$ of the potential yield gaps available in the currently cultivated dwarf varieties of irrigated ecology needs to be bridged. A study by ${ }^{36}$ reported that yield levels of 5-6 tonnes per hectare were being realized by the most efficient farmers, except in Orissa where even the best farmers could not reach beyond 2.5 tonnes. This raises questions regarding real gaps. Also regarding potential for future growth, these findings make assertions regarding yield ceilings in states like Punjab. In addition, augmentation and extensive adoption of hybrid technology in irrigated ecology is essential.

The remarkable increase in production and productivity of wheat at increasing rate since independence is a land mark achievement in Indian agriculture. It seems still wheat crop has tremendous yield potential. Exploitation of this potential would be possible through stepping up the yield level in the NEPZ (9 m.ha) to around $3 \mathrm{t} / \mathrm{ha}$ from the presence level of $2.25 \mathrm{t} /$ ha through varieties adapted to late sown conditions.

The area under maize is declining at a faster rate though its productivity is increasing at an increasing rate. The strategies to increase maize productivity are development and popularization of quick maturing hybrids and composites of maize for the rain-fed regions. And also emphasis should be given for the development of single cross, full season and medium maturing hybrids for rain fed and irrigated rainy season and winter season.

Soya bean is one of the important pulse and oilseed crops as well. There is need to allocate more area under this crop and to bridge the need of pulse and oil seeds demand and explore comparative yield, protein and industrial advantage. The productivity growth of this crop is declining. There is urgency to break through production constraints to achieve further yields.

Hitherto, a meager productivity improvement was made in groundnut. The area under groundnut had also declined. The accomplishment of groundnut production would possible through increase in area allocation and improvement in yields of HYV's. Though, the productivity of jute had been increasing steadily, the area under this crop declined at faster rate. There is need to increase more area under jute to take advantage of commercial value.

The productivity of sugarcane over the years improved and its productivity seems to have stagnated. The strategies to be adapted to breakthrough yield barriers are development 
of high sugar varieties with resistance to red rot and development of early, medium and late maturing varieties adapted to drought and water logged conditions. Rebuilding of gene pool involving improved ecotypes of constituent species of the genus Saccharum does needs priority.

The production of cotton during different periods is quite impressive. Though the productivity of cotton is increasing at an increasing rate the area under cotton declined at faster rate. Still further yield improvement would be possible by insulation of all varieties or hybrid cotton with high level of resistance to bollworm complex and sucking pests. Development of early maturing or hybrids well adapted to most prone area needs attention. The area under tobacco declined continuously at faster rate in all the periods. This is because of government policy restriction on allocation of more area under tobacco.

Above all, the need for more food has to be met through higher yields per unit of land, water, energy and time. Further, explore the possibilities to increase yields by using modern inputs to boost yields levels and growth of out put. India is fortunate to have a large arable land, which many other nations do not have. Sow seed of success is a reformist blueprint for second green revolution. Investment in infrastructure instead of direct subsidies; special program for irrigation; diversification and intensification of cropping pattern would definitely boost yields.

Fortunately, as we approach the new millennium we are experiencing three major revolutions in science and technology in a fundamental manner.

- The gene revolution: it provides a molecular understanding of the genetic basis of living organisms, as well as the ability to use this understanding to develop new processes and products for agriculture, the environment and for human and animal health.

- The information and communication revolution: it allows rapid growth in the systematic assimilation and dissemination of relevant and timely information, as well as a improved access ability to the universe of knowledge and communication through low cost electronic net works, and

- The Eco technology revolution - it promotes the blending of the best in traditional knowledge and technology with frontier technologies, renewable energy and new materials.

- Nanotechnology:

In principle, these three types of advance- when coupled with improvements in management science and governancegreatly increase the power of a scientific approach to genetic and agronomic improvement and the integrated management of local and regional developmental policies.

\section{Conclusion and Future Research}

Scientists must unlock the many secrets of the sunlight plant - water - nutrient - soil relations that are the fundamental blocks upon which agricultural science rest. Clearly, in the years ahead, the focus of research should be on expanding food deficit regions where the majority of the hungry people live. In a number of these regions land will remain the major provider of food for increasing populations. Research should help to increase the productivity of small plots and address the specific problems of poor farmers in these regions. In particular, research leading to the improvement of "orphan commodities" such as, coarse grains, pulses and vegetables needs attention.

The need for continuing aggressive research in all of these areas and across many disciplines by the national research centers is very much required. The activities would be focused on commodities and selected subject matter areas, such as policy, management, conservation of germplasm and the maintenance of biodiversity. Ecoregional activities would focus on applied and strategic research on the ecological foundations of sustainable production systems, and commodity improvement.

The impressive transformation would be possible due to major factors such as (i) Land reforms (ii) Creation of infrastructure such as irrigation, seed production and manufacture of fertilizers (iii) Building of a strong particular R\&D system, and (iv) Human resource development.

\subsection{Ever Green Revolution}

Self-reliance in food grains is perhaps our most significant achievement. If the current production is an indication, meeting the projected demand of 220 million tonnes by 2020 $\mathrm{AD}$ will not be difficult. Integration of the philosophies of green to red revolutions with sustainable manner would lead to country to attain Ever green revolution.

To achieve this, the country need to reformulate the agricultural policies, which must focus on area allocation policy and agricultural productivity policies. Agriculture is being in the state list the center is needed to take consensus of state governments. The area allocation under different crop sectors and principal crops must be based on spatial and temporal comparative yield advantage with same existing allocation of land. Further, there is a need to make comprehensive integrated policy of cropping and farming systems with incorporation of crops, fisheries and livestock farming. Perhaps, these may require cooperation and coordination from farmers. Farmer may not be inclined to change the adopted structured land use-cropping pattern but through price support mechanisms and other incentives this could be achieved. Further, the country needs to formulate national productivity policies suited to the crops, which have comparative yield advantage. Technologies have to generate to increase the productivity of the major crops and a strong extension need to be put in place to reach these technologies to the farmers.

\section{Acknowledgements}

The authors would like to thank the whole researchers who directly or indirectly helped working on this article and all on-line and offline resource providers. 


\section{References}

[1] Calibre (2012) FAO OECD Agricultural Outlook: Looming food crisis.

[2] FAO (2011) Investing in agriculture for a better future. The State of Food and Agriculture 2012, Publication.

[3] FAO (2012) World agriculture towards 2030/2050: the 2012 revision. ESA Working paper No. 12-03.

[4] Kenneth A. Dehlberg, 1995, Global research on the environmental and agricultural nexus for the 21st century; Report of the Taskforce on Research Innovations for Productivity and sustainability: University of Florida, and University of Collarado.

[5] Dastagiri M.B., (1998) 'World Food Production Research' Out Look on Agriculture, Vol. 27(2), June 1998, pp. 77-80.

[6] Jacob L. Weisdorf From foraging to farming: Explaining the Neolithic Revolution; Journal of Economic Surveys Vol. 19, No. 4, 2005.

[7] Walker, M., Johnsen, S., Rasmussen, S.O., Popp, T., Steffensen, J.-P., Gibbard, P., Hoek, W., Lowe, J., Andrews, J., Bjorck, S., Cwynar, L. C., Hughen, K., Kershaw, P., Kromer, B., Litt, T., Lowe, D. J., Nakagawa, T., Newnham, R., and Schwander, J. 2009. Formal definition and dating of the GSSP (Global Stratotype Section and Point) for the base of the Holocene using the Greenland NGRIP ice core, and selected auxiliary records. J. Quaternary Sci., Vol. 24 pp. 317. ISSN 0267-8179.

[8] Hole,F,1984., A Reassessment of the Neolithic Revolution, Paléorient, Vol.10, Issue 10-2, pp. 49-60

[9] Grinin,L.E. Production Revolutions and Periodization of History: A Comparative and Theoretic-mathematical Approach. / Social Evolution \& History. Volume 6, Number 2 / September 2007

[10] Watson, Andrew M (1974), "The Arab Agricultural Revolution and Its Diffusion, 700-1100", The Journal of Economic History 34 (1): 8-35

[11] Ayyappan, S, 1977; 'Aquaculture towards a blue revolution' Survey of Indian Agriculture, pp117-122.

[12] Watson, Andrew M 1983), agricultural Innovation in the Early Islamic World, Cambridge University Press, ISBN 0521-24711-X.

[13] Decker, Michael (2009), "Plants and Progress: Rethinking the Islamic Agricultural Revolution", Journal of World History 20 (2): 187-206, doi:10.1353/jwh.0.0058.

[14] Christian Bonte Friedhein et.al (1997), 'Agriculture and Globalization: The evolving role of Agricultural research' the globalization of Science: The place of Agricultural Research, ISNAR, Hague, Netherlands, 1997, pp. 1-14.

[15] Overton, Mark (19 September 2002). Agricultural Revolution in England 1500 - 1850. Cambridge, England: Cambridge University Press. ISBN 0-521-56859-5.

[16] Thirsk, Joan. "'Blith, Walter (bap. 1605, d. 1654)"'. Oxford Dictionary of National Biography, Oxford University Press, 2004; online edition, Jan 2008. Retrieved 2 September 2011.
[17] British food puzzle, offline document, 6 Apr 2012.

[18] Overton, Mark (19 September 2002). Agricultural Revolution in England 1500 - 1850. Cambridge, England: Cambridge University Press. ISBN 0-521-56859-5.

[19] Devine, Thomas Martin. The transformation of rural Scotland: Social change and the agrarian economy, 1660 181,1994

[20] Watson, Andrew M (1981), "A Medieval Green Revolution: New Crops and Farming Techniques in the Early Islamic World", the Islamic Middle East, 700-1900: Studies in Economic and Social History.

[21] University of Florida Digital Collections (UFDC). http://ufdc.ufl.edu/UF00053937/00001

[22] Sharma RP, 1997 'India- the Bowl of Agricultural production', Indian Farming, August 1997, pp.7.

[23] IFPRI-2003 Report. www.ifpri.org/publication/2003-2004ifpri-annual-report

[24] Annual Reports of CGIAR www.cgiar.org

[25] Prabhu L. Pingali, PNAS, 2012, vol. 109 no. 31, 12302 12308, doi: 10.1073/pnas.0912953109.

[26] Webb PJR (2009): For a World Without Hunger, ed Eiselen H (HamppMedia/Balance publication, Stuttgart), pp 410 434.

[27] Burney JA et al. Greenhouse gas mitigation by agricultural intensification. PNAS USA 107:12052-12057 (2010).

[28] Pingali PL, Rosegrant MW (1994) Confronting the Environmental Consequences of the Green Revolution in Asia (International Food Policy Research Institute, Washington, DC).

[29] Swaminathan, M.S. Wheat revolution: a dialogue. Macmillan India Ltd, 1993.

[30] Swaminathan et al. Science 3 1982: vol. 218:4576 pp. 967972.

[31] Pedro A. Sanchez, M. S. Swaminathan; Science Vol 307: 212005.

[32] ICRA 2011, Indian Poultry Industry - Broiler Meat and Table Egg FAO yearbook. Fishery and Aquaculture Statistics. 2009. FAO yearbook. Fishery and aquaculture statistics.

[33] ICRA, 2011, Handbook of Fisheries statistics, 2011.

[34] Central Statistical Organization (CSO), 2012, Report of Central Statistics Office 2012.

[35] Dastagiri, M. B. 2013 "Global agricultural policies: reforms and future agriculture", Agriculture Forestry and Fisheries $2013 ; 2(1): 11-22$

[36] Jha D, 1996 'Research Accomplishment under the major program areas of NCAP' NCAP Annual Report, 1996-97, pp 3-7. 